\title{
ARTIGOS
}

\section{O CATECISMO DE MONTPELLIER \\ E A EDUCAÇÃO DA CRIANÇA \\ NO BRASIL IMPERIAL}

JUAREZ JOSÉ TUCHINSKI DOS ANJOS

\section{RESUMO}

Partindo da hipótese que os catecismos católicos, na interpretação dada ao quarto mandamento, colocavam em circulação representações sobre a educação da criança pela família, o objetivo deste artigo é identificar como tal educação era concebida no Catecismo de Montpellier, a fim de compreender de que modo ela servia aos interesses do Estado Regalista no Brasil Imperial.

CATECISMOS • EDUCAÇÃO • BRASIL • SÉCULO XIX

THE CATECHISM OF MONTPELLIER AND CHILDREN'S EDUCATION IN BRAZIL IMPERIAL

\section{ABSTRACT}

Based on the assumption that the catholic catechisms, in its interpretation of the fourth commandment, brought to light representations of children's education in the family, the aim of this article is to identify how such education was conceived in the Catechism of Montpellier in order to understand how it served the interests of the Regalist State in the Imperial Brazil. 


\section{LE CATÉCHISME DE MONTPELLIER ET L'ÉDUCATION DES ENFANTS À L'ÉPOQUE DU BRÉSIL IMPERIAL}

RÉSUMÉ

L'interprétation du quatrième commandement que les catéchismes catholiques, mettaient en circulation sur les représentations de l'éducation familiale des enfants sert d'hypothèse à cet article que vise à identifier comment une telle éducation était conçue par le Catéchisme de Montpellier, afin de comprendre de quelle façon elle servait les intérêts de l'Etat Régaliste à l'époque du Brésil Impérial.

CATÉCHISMES • ÉDUCATION • BRÉSIL・XIX SIÈCLE

RESUMEN

Partiendo de la hipótesis de que los catecismos católicos, en la interpretación del cuarto mandamiento, ponían en circulación representaciones sobre la educación del niño por parte de la familia, el propósito de este artículo es identificar como esa educación era concebida en el Catecismo de Montpellier con el fin de entender cómo servía a los intereses del Estado Regalista en Brasil Imperial. 

estudo as práticas de educação da criança pela família no Brasil Imperial, mais especificamente na Província do Paraná (1853-1889), observei que essa educação foi objeto de disputas entre o Estado e a Igreja, que, visando a instaurar uma relação de poder entre si e sobre a família, produziram diferentes representações ${ }^{1}$ acerca de como as crianças deveriam ser educadas por seus pais e mães no período. Uma das três representações identificadas foi produzida pelo Estado Imperial no bojo do regalismo. ${ }^{2}$

O regalismo foi a doutrina política segundo a qual o soberano

Este artigo é versão ampliada e aprofundada de comunicação apresentada no $\times$ Congresso Luso-Brasileiro de História da Educação.

Pesquisa financiada pela Coordenação de Aperfeiçoamento de Pessoa de Nível Superior - Capes.

Por representação entendo, com Roger Chartier (2002 p. 17), aqueles "esquemas intelectuais incorporados que criam figuras graças às quais o presente pode adquirir sentido, o outro tornar-se inteligivel e o espaço ser decifrado".

As outras duas representações são a ultramontana e a liberal. tinha o direito de intervir na vida da Igreja Católica de seu país, o que resultava na submissão dessa instituição ao Estado. Tal doutrina, em Portugal, consolidou-se durante o governo de D. José (1750-1777), auxiliado por seu ministro, o Marquês de Pombal. No Brasil, como herança da colonização, no pós-independência, as relações entre Igreja e Estado, durante todo o Império, confirmadas já na Constituição de 1824, foram as de um catolicismo regalista constantemente marcado pela ingerência do poder temporal no espiritual. Essa posição era geralmente aceita por força do regime do padroado, outra herança colonial. Esse acordo com a Santa Sé estabelecia que a manutenção financeira da Igreja deveria correr por conta dos cofres públicos, o que fazia dos padres e bispos uma espécie de funcionários estatais. Alguns, inclusive, ocupavam cargos e funções importantes na máquina administrativa. Vários bispos foram senadores e presidentes de províncias ao passo que inúmeros sacerdotes 
eram igualmente políticos, atuando desde as câmaras municipais, em modestos recantos do país, até as altas esferas do Conselho de Estado, chegando um deles, padre Diogo Feijó, à condição de Regente do Império na década de $1830 .^{3}$ Em contrapartida, era assegurado ao Imperador, pelo padroado, o placet ou beneplácito régio, o direito de aprovar ou não as determinações papais e sua aplicação no território nacional. Tal privilégio garantia, dentre outros, que a Igreja em nível local permanecesse, não apenas financeira mas também pastoralmente, sob o jugo imperial.

De acordo com a documentação consultada, o regalismo, conforme praticado no Império Brasileiro, aliado ao padroado, acabou por conferir lugar de proeminência à religião católica, não por ela em si, mas por ser a religião do Estado, aquela que deveria fornecer-lhe sustentação ideológica para sua consolidação. Com efeito, ao submeter o poder espiritual ao temporal, o Estado submetia também a doutrina religiosa aos seus interesses, dentre os quais estava o de produzir na população o respeito e a obediência às instituições em fase de implantação (como a lei) e ao governo, na pessoa do Imperador e de seus representantes, na burocracia estatal e judiciária. É nesse quadro que a educação da criança pela família ganhou importância. Um dos testemunhos nos chega por meio de alguns catecismos cujo conteúdo, ainda que produzido por vezes em contextos diversos, era passível de interpretação de cunho regalista quando adotado e recomendado pela Igreja, sob os ditames do governo, para uso do clero e dos fiéis.

De maneira recorrente, na historiografia da educação brasileira sobre o Oitocentos, os catecismos aparecem nas pesquisas ligadas ao ensino da leitura nas escolas elementares públicas na condição de manuais utilizados no aprendizado da religião e da moral. É o caso dos trabalhos de Elomar Tambara (2005), Luiz Eduardo Oliveira e Leda Corrêa (2006) e Giselle Baptista Teixeira (2008), dentre outros. Também nas escolas protestantes esse tipo de impresso tinha a mesmíssima utilidade, como apontou Ester Nascimento (2005) em sua tese de doutoramento.

Contudo, os catecismos não serviram apenas de suporte para a leitura e a escolarização: foram também veículos que colocavam em circulação determinadas representações sociais (CHARTIER, 2002) sobre um tipo de educação de matriz religiosa a ser dada pelos pais aos filhos. Tal educação, entendida como um conjunto de atitudes, hábitos, comportamentos e condutas a serem aprendidos desde a infância, deveria levar à assimilação e naturalização de um modelo de relações cotidianas a ser estabelecido entre os membros da família e com a sociedade da qual faziam parte. Era veiculada nesses catecismos, de modo especial, a parte relativa à interpretação dada ao quarto mandamento: Honrar pai e mãe. Em face do exposto e tomando-o como hipótese, o objetivo deste artigo é identificar como essa educação era concebida no Catecismo de Montpellier - um dos que tiveram maior circulação no

3 Essa situação só começou a ser questionada, por parte da hierarquia católica brasileira, a partir da segunda metade do século XIX, quando teve início o movimento de reforma ultramontana, que pleiteava maior autonomia para a ação pastoral e institucional da Igreja Católica. 
Império $^{4}$ - a fim de compreender de que modo ela servia aos interesses do Estado Regalista no Brasil do século XIX.

Para dar conta desse objetivo, na primeira parte do artigo apresento alguns dados historiográficos sobre a produção, circulação e usos políticos e religiosos do Catecismo de Montpellier entre os séculos XVIII e XIX que ajudam a entender o motivo de esse impresso ter se tornado, no curso de um longo processo histórico, tão caro ao regalismo português e brasileiro, apesar das condenações papais que o acompanhavam desde pouco tempo após sua publicação original. Na segunda parte, investigo, mais especificamente, as relações que, na Província do Paraná, eram estabelecidas entre a educação religiosa da criança pela família e a produção de condições de governabilidade que passava pela transmissão da doutrina religiosa, a mesma que era veiculada no Catecismo de Montpellier. Na terceira parte, procedo à análise das representações sobre os conteúdos da educação da criança pela família veiculadas na interpretação que fazia do quarto mandamento da Lei de Deus, que manda os filhos honrarem ao pai e à mãe. Ao final, encerro o texto com algumas considerações, à guisa de conclusão.

\section{NOTAS SOBRE A PRODUÇÃO E OS USOS POLIITICOS DO CATECISMO DE MONTPELLIER}

O Catecismo de Montpellier foi impresso pela primeira vez em 1702, na diocese homônima. Seu autor era o oratoriano François Aimé Pouget, reitor do seminário diocesano (SANTIROCCHI, 2010). A obra foi-lhe encomendada pelo bispo de Montpellier, Joachim Colbert. O impresso saiu circulação do Catecismo de Montpellier durante o Império se deu em meio à proliferação de diversos textos catequéticos produzidos no período tanto na Europa como no Brasil (cf. TAMBARA, 2003 ORLANDO, 2008). IsSO anuncia, assim, que houve diferentes representações da doutrina católica em disputa no Oitocentos, como foi o caso daquelas postas em circulação nos catecismos ultramontanos, como o redigido por D. Joaquim Antonio de Melo bispo de S. Paulo, em 1860, que, como assinala Augustin Wernet (1987), alcançou inúmeras reedições. Todavia, as representações contidas no Catecismo de Montpellier, por razões que serão examinadas mais adiante, alcançaram hegemonia entre os defensores do regalismo no interior do Estado Imperial. dos prelos trazendo em si as marcas de dois movimentos de impacto na França desde meados do século anterior: o galicanismo e o jansenismo.

O galicanismo, de cunho político, visava a diminuir o poder papal no país, concedendo maior espaço de decisão aos bispos em suas jurisdições, possibilitando, com isso, o fortalecimento do absolutismo de Luís XIV (GRES-GAYER, 2004). O jansenismo, de cunho religioso, propunha uma interpretação da doutrina da Graça e da moral marcadas por um pessimismo teológico que via "na criança e no homem pessoas roídas pela malícia completa” (NUNES, 1981, p. 78), o que resultava em uma visão contrária à ortodoxia do Concílio de Trento e próxima da ótica luterana e calvinista da questão, e o colocava sob a suspeita de heresia. O primeiro movimento, apesar dos acordos firmados entre o Rei e a Santa Sé, manteve sua força ao longo do século XVIII. Já o segundo, apreciado inicialmente por Luís XIV - que também sustentava que o poder da Igreja local deveria ser maior que o de Roma sob o comando do Monarca -, passou a ser objeto de sua perseguição, uma vez que, desde fins do Seiscentos, estava pondo em acirrado conflito os jansenistas e os jesuítas, estes últimos fiéis à ortodoxia e ao Papa. Três anos após a 
publicação do Catecismo de Montpellier, em 1705, a situação tornou-se tão insustentável que o Rei Sol pediu a intervenção papal (!) para dar fim à polêmica, conforme explica detalhadamente em sua História da Igreja, Giácomo Martina (2003).

Fruto do seu tempo e das representações dos atores que o produziram, o Catecismo de Montpellier fazia, em suas lições, por um lado, forte defesa da autoridade temporal e episcopal, o que o tornava simpático ao galicanismo. Por outro lado, vinha embebido no pessimismo teológico jansenista: pregava a necessidade da vigilância e submissão do fiel à autoridade humana, sinal visível da autoridade divina, única capaz de salvar sua tão machucada alma. O impresso, com todas essas qualidades, foi um best-seller do seu tempo: em 1731 já contava 20 edições (SANTIROCCHI, 2010). O sucesso só não foi maior porque Joachim Colbert, bispo de Montpellier, apesar de ter permanecido fiel ao galicanismo na questão do jansenismo (do qual era adepto assim como o oratoriano Pouget, autor efetivo do texto), não aceitou a condenação papal de 1705 ao movimento, o que o colocou em conflito declarado com Luís XIV, tornando-o um religioso odiado pelos jesuítas e ultramontanos. A ira dos opositores alcançou não apenas o prelado (que, desgostoso, optou por viver recluso na diocese até o fim da vida), mas também seu catecismo, incluído no Índex dos livros proibidos por Roma em 1721.

Em que pese isso, o Catecismo de Montpellier continuou sendo largamente utilizado, pois, salvo sua polêmica teologia jansenista, o espírito de obediência e submissão à autoridade que ele pregava continuava bastante oportuno ao galicanismo na França. Mesmo seus opositores reconheciam o enorme sucesso da obra, conforme testemunha o exame teológico a que foi submetida quando de sua condenação: "Não somente os catequistas se servem dele para instruir a juventude, mas a maior parte das famílias católicas o deseja para ensinar a seus filhos as primeiras tinturas da nossa religião” (DURAND, 1907, p. 75, tradução minha). Entretanto, por ser considerado o Catecismo de Colbert, carregou a poderosa marca de um opositor de Roma. Num desses paradoxos históricos, apesar de suas tendências galicanas, seu jansenismo tornou-o incômodo ao governo francês no momento em que esse precisou do Papa para condenar os religiosos jansenistas que ameaçavam a paz no país. Concomitantemente, esse mesmo paradoxo o tornaria particularmente adequado a outro monarca que queria, justamente, afastar-se de Roma e reforçar sua autoridade temporal em face da religiosa. Foi o que se deu em Portugal.

Durante o Reinado de D. José e no embalo das reformas pombalinas - período de implantação de um despotismo esclarecido que tinha como uma de suas justificativas a necessidade de modernização administrativa e intelectual da Lusitânia e seus domínios, o que significava, dentre outras medidas, expulsar os jesuítas dos campos tradicionais de 
atuação, recusar tudo o que pudesse evocar sua influência e diminuir o poder ali exercido por Roma (mas sem romper com ela!) -, com a colaboração de D. João Cosme da Cunha, Arcebispo de Évora, foram realizadas a tradução e a adoção do Catecismo de Montpellier para uso dos sacerdotes, das famílias e dos escolares, em 1765. Na ocasião, D. João Cosme, ciente das críticas que poderia sofrer em face da presença do texto no Índex desde 1721, escreveu a instrução pastoral na qual fazia defesa do livro e de sua utilidade para a realidade portuguesa. Para ele, a inclusão da obra no Índex fora fruto da inveja dos jesuítas,

[...] êmulos implacáveis de todo livro bom, que saiu à luz pública sem levar estampado o seu nome e inimigos declarados dos bispos em toda conjunção [...] procuram abater o crédito de um livro que tinha recebido na Igreja um aplauso universal. (CUNHA, $1765^{5}$ apud SANTOS, 2007, p. 121)

Outro ponto abordado revela, indiretamente, a percepção que tinham os governantes portugueses e o próprio mitrado do quão adequado eram os ensinamentos de Montpellier no momento em que Portugal estava consolidando o regalismo - doutrina política de submissão da Igreja ao poder temporal - e enfraquecendo, com isso, a autoridade papal no reino, da qual os jesuítas eram incansáveis defensores. Falava o bispo:

No alfabeto deste livro [o catálogo de obras jansenistas, organizado pelos jesuítas] se encontra o nosso Catecismo de Montpellier. Nem podia deixar de ser assim, porque na sua primeira parte, seção primeira, capítulo IV, parágrafo 21 desta admirável obra, recomenda muito o mesmo Catecismo a fidelidade que os vassalos devem ter aos seus soberanos, provando com sólidas razões que não há caso em que seja permitido o rebelar-se contra a autoridade legítima dos Reis, nem ainda com pretexto de perseguição ou de Religião, etc. Ora, todos sabem que esta doutrina é inteiramente oposta às máximas da Sociedade [= Jesuítas] e por isso o Catecismo de Montpellier ou havia de ser Jansenista ou ficar compreendido no jansenismo. (CUNHA, 1765 apud SANTOS, 2007, p. 121)

Com todas essas "qualidades”, a obra dava ensejo para que D. José e o Marquês de Pombal solucionassem vários problemas de uma só vez, como bem sintetiza Cândido dos Santos (2007, p. 38):

O jansenismo do catecismo de Montpellier é um jansenismo "mitigado", que o poder usou como um aliado tático. Nada mais. Era regalista, conciliarista, anticúria romana, antijesuítas. Que mais queria o despotismo iluminado? 
De Portugal, foi rapidamente adotado no Brasil, então colônia ibérica, por efeito das reformas pombalinas, e por ali o Catecismo de Montpellier alcançou longevidade, sendo utilizado nas escolas brasileiras, mas também na catequese da Igreja e na família, até mais da metade do século XIX. De acordo com Riolando Azzi, “um alvará do governo português de 30 de setembro de 1770 mandava utilizar nas escolas do Brasil manuscritos ou livros impressos, principalmente o catecismo pequeno de Montpellier" (1977, p. 498). Evergton Sales de Souza (2005), investigando a presença do jansenismo no Brasil Colonial, indica que na Diocese de São Paulo esse catecismo chegou com D. Frei Manuel da Ressurreição, que esteve à frente do bispado de 1771 a 1779, ocorrendo o mesmo nas Dioceses do Rio de Janeiro e Pernambuco. De novo Riolando Azzi, falando do espírito político de fins do Setecentos, observa que, "ao mesmo tempo em que prescrevia o Catecismo de Montpellier, a corte lusitana se preocupava com a influência das novas ideias revolucionárias, que despertavam no povo a ideia de independência" (1977, p. 498). Para evitar isso, "recomendava que no ensino do catecismo se continuasse a inocular a necessidade do respeito e da obediência às autoridades constituídas” (AZZI, 1977, p. 498).

Após a independência política do Brasil, ocorrida em 1822, no momento em que o Estado brasileiro em formação afirmava-se como liberal e regalista, o Catecismo de Montpellier continuou a contribuir com a produção de submissão e respeito à autoridade, a mesma de que foi instrumento na França e em Portugal, nesse último caso num sentido de continuidade, já que o regalismo português tornou-se o regalismo brasileiro. Sua permanência se explica pelo idêntico motivo que o fez afirmar-se em Portugal: veicular uma doutrina religiosa submetida ao Estado, favorável a ele e capaz de inculcar nos católicos a obediência primeiro ao Rei, porque era vontade de Deus e, depois ao Papa, que vivia bem mais longe do que aquele soberano da nação.

No Brasil, o liberalismo daria nova roupagem ao regalismo, fazendo com que a obediência ao Rei, originalmente defendida em Montpellier, se convertesse na obediência ao Estado, a todo o aparelho administrativo por ele engendrado e, particularmente, às leis que organizavam a vida de todos os súditos. No Paraná, nos primeiros anos de existência da Província, esse era o catecismo utilizado na escola e também pelos padres de formação iluminista na instrução dos fiéis, assim como pelos próprios fiéis que, possuindo o domínio da leitura, poderiam servir-se dele no interior de suas famílias.

Mas como é que o Catecismo de Montpellier podia realizar essas “proezas” de promoção da coesão social e política aos olhos do regalismo brasileiro? Para obter uma resposta, devemos analisar com vagar o lugar que a educação religiosa da criança pela família ocupava nas preocupações das autoridades do Estado Imperial brasileiro, tomando como ilustrativo o caso da Província do Paraná. 


\section{A EDUCAÇÃO (RELIGIOSA) DA CRIANÇA PELA FAMÍLIA: SEU LUGAR NO ESTADO REGALISTA}

A Província do Paraná, antiga $5^{\text {a }}$ Comarca de São Paulo, foi desmembrada desta e instalada oficialmente em 19 de dezembro de 1853 (embora a lei que a criou seja de agosto do mesmo ano). Na condição de última província criada no Segundo Reinado - e, portanto, a sempre mais nova, na qual se dizia que tudo estava por fazer -, se constitui num interessante espaço histórico no qual os fenômenos globais vivenciados na conjuntura do Império Brasileiro, em particular a produção do Estado e de condições de governabilidade, podem ser observados e analisados de forma privilegiada.

Os presidentes da província paranaense, representantes locais do poder central, ao tratarem de um tema caro à sua administração - a segurança individual e a propriedade -, também esbarravam numa realidade rebelde ao esforço de governabilidade ao qual agentes imperiais nas mais diversas províncias estavam lançando-se e que incluía, dentre uma gama de responsabilidades, combater a criminalidade contra a pessoa ou seus bens. Para eles, a causa fulcral dos crimes era a falta de educação moral e religiosa da população. Contudo, para compreender como essa complexa relação apresentava-se a seus olhos, é preciso, ao historiador, levar em conta pelo menos quatro variáveis: as causas da criminalidade, o papel atribuído à religião em face delas, a situação religiosa na província e as responsabilidades que esses fatores impunham a determinados atores sociais do período em termos de uma prática capaz de modificar essa realidade - a educação da criança pela família.

Em 1857, ao transmitir o cargo para seu sucessor, o presidente Antonio Vaz de Carvalhaes discorreu do seguinte modo sobre as causas da criminalidade na jovem província paranaense:

A segurança individual e da propriedade continua a ressentir-se do atraso da educação do povo, da defeituosa organização da administração da justiça e dos escassos recursos de que dispõe a polícia. [...] É fora de dúvida que a insuficiência da força pública para as necessidades do serviço policial, o péssimo estado das prisões e a sua falta absoluta em algumas localidades que delas necessitam, tem tido muita parte na existência dos crimes cometidos neste ano na província, que visivelmente se conhece, não poderem ser somente os enumerados no relatório a que me tenho referido; mas é também incontestável que, ainda quando fosse possivel colocar ao lado de cada cidadão um sentinela, e em cada quarteirão uma cadeia com a competente bulha de correntes e algemas, nem por isso o crime deixaria de ser frequente e de ostentar-se revestido de circunstâncias atrozes, se, pela disseminação do ensino e propagação da moral evangélica pelas classes inferiores não se the 
Descontadas as causas estruturais (como falta de policiais, de prisões e precariedade da administração da justiça), o presidente que dava adeus ao cargo considerava que mesmo se solucionados um a um os problemas enfrentados e se chegasse ao impossível ponto de haver um guarda para ficar no encalço de cada cidadão, de nada isso adiantaria se não fosse levantada a única barreira capaz de estorvar o passo da criminalidade: o ensino (numa possível alusão à escola) e a propagação da moral evangélica sobre as classes inferiores, isto é, do correto agir informado pelos valores do cristianismo. Essa diferenciação feita pelo presidente revela que não se considerava ser a todos os paranaenses que faltavam tais valores religiosos para um bem agir, mas àqueles vindos dos estratos mais "inferiores" de uma sociedade hierarquizada numa província em fase de organização. Ele próprio, no relatório que apresentara meses antes à Assembleia Provincial, naquele mesmo ano de 1857, fora bastante incisivo sobre essa cisão existente no Paraná entre os que caminhavam na senda da justiça e os que dela se apartavam pelo crime, deixando claro "quem era quem" na história:

\footnotetext{
Sobre as violações da segurança individual, devo ainda observar que são elas sempre perpetradas por indivíduos pertencentes às últimas camadas da população que, privados do menor desenvolvimento intelectual, vivem abandonados aos mais brutais instintos. Exigir de homens constituídos em tais condições, que se abstenham de cometer crimes, é quase tão absurdo como exigir dos cegos que caminhem sem tropeçar. (CARVALHAES, 1857a, p. 13)
}

Essa representação acerca da criminalidade fraturava a sociedade em, ao menos, dois grupos: o dos morigerados e moralizados (a quem, portanto, cabia o governo da situação) e o das últimas camadas da população, de quem, sem que lhes fosse dada uma educação religiosa adequada que os moralizasse, muito pouco se poderia exigir em termos de conduta. $\mathrm{O}$ fato de a fala presidencial ter em vista um estrato específico da população não deve levar-nos a minimizar o alcance das representações que enuncia, já que manifestam a vontade de impor uma representação a uma classe que não é aquela da qual o presidente faz parte; porém são os valores da sua classe que ele deseja impor às demais, evidenciando, assim, uma relação de força que visava a instaurar um poder sobre o outro por meio da educação.

O problema do controle dos crimes e dos criminosos esbarrava em outra questão interessante e bem própria de uma província recém-emancipada: o reconhecimento da autoridade sobre uma população 
que, até então, vivia num espírito de letargia - bastante favorável para retardar sua emancipação como quinta comarca paulista, mas problemático agora, num quadro em que tudo estava por ser feito e as condições de governabilidade, em vias de produção. Sobre isso, quem nos fala é o presidente Teóphilo Rezende, em relatório datado de 6 de setembro de 1855:

Não rematarei este capítulo sem dizer que, em regra, nenhum criminoso ou recruta se entrega à prisão quando se lhe dá a voz sem tentar o meio de resistência; o primeiro e imediato impulso da gente da província que se procura capturar ou prender é da resistência com arma, de que não prescinde, sendo talvez por isso que se produzem os crimes das escoltas. (REZENDE, 1855, p. 10-11)

Mas em que a religião poderia contribuir para a mudança de toda essa complexa situação na ótica defendida pelos administradores provinciais?

Henrique Beaurepaire Rohan, que governou durante parte de 1856, delineou com muita clareza o papel a ser desempenhado pela religião no quadro geral da sociedade paranaense e, por consequência, a importância da educação religiosa em falta. Lamentando as dificuldades para que todas as paróquias fossem providas com vigários para o serviço do povo, Beaurepaire Rohan relatava que "a presidência não tem cessado de pedir remédio a este estado de desmantelamento, que dificulta os exercícios da religião, tão necessários para moralizar o povo e adoçar os seus costumes” (1856, p. 22). Para o administrador, a ausência de ministros tinha reflexos diretos na conduta da população, que, sem assistir aos ritos da religião - as missas, batizados e casamentos -, deixava de receber com tais sacramentos os valores ideológicos necessários para sua moralização. E mais: esses valores temperavam os xucros paranaenses, tornando-os, portanto, mais dóceis em seus costumes e assim mais maleáveis aos deveres que o status de membros da mais nova província do Império também lhes impunha.

Transcorridos mais de 20 anos, o presidente Rodrigo Otávio de Menezes também afirmava que "a influência da religião na sociedade é coisa que não se discute” (1879, p. 41). Contudo, se sua importância e poder na produção da coesão social permaneciam indiscutíveis, bem mais discutível era a situação da própria religião na Província do Paraná:

O culto público, salvo uma ou outra freguesia, onde o vigário por exceção está à altura do cargo, causa lástima. [...] As igrejas destes, criminosamente abandonadas, excluem a ideia de uma casa de Deus. Já entrei em uma matriz cujas portas à noite não se fechavam 
É certo que havia, ao menos na situação relatada por Rodrigo Otávio (1879), uma boa dose de desmazelo da parte dos vigários, alguns inclusive deixando as igrejas abertas após o pôr do sol. Mas o povo, via de regra, também não era tão zeloso - ao menos aos olhos dos presidentes da província - em matéria religiosa. Ou, pelo menos, na representação da vivência religiosa ideal partilhada por eles. O já mencionado Teóphilo Rezende não hesitava em afirmar, em seu relatório, o atraso em que viviam os paranaenses nessa matéria:

\footnotetext{
Disse meu predecessor [Zacarias Goes de Vasconcelos] em seu relatório de 15 de julho de 1854, que era verdadeiramente excepcional, a certos respeitos, o estado do culto na Província. Se devo guiar-me pelo que a este respeito observei na própria capital, força é confessar que seu atraso, a indiferença do povo sobre matéria da religião e algumas práticas irreverentes e ridículas, dão mostra do que seria e, ainda é na província, este importantíssimo objeto. (REZENDE, 1855, p. 35)
}

Então, a quem caberia dar a educação religiosa a essa população irreverente e descuidada de assunto tão magno, assunto que tinha, inclusive, influência nas estatísticas criminais da Província? Em 1864, fazendo eco a seus predecessores, o presidente José Joaquim do Carmo julgava ser ela responsabilidade fundamental dos sacerdotes, responsabilidade que não estariam assumindo a contento. Segundo ele, "pouco se esforça o clero do Paraná na grande obra da regeneração dos costumes pela palavra religiosa" (CARMO, 1864, p. 3), isto é, os padres não estavam sabendo colocar a serviço do Estado a ideologia eclesial que deveria regenerar, modificar, purificar os costumes dos paranaenses. E continuava:

Se os párocos, compenetrando-se de sua missão apostólica se esforçassem por difundir a palavra divina e a moral do Evangelho, por todos os meios que seu ministério Ihes proporciona, talvez lenta e vagarosamente, mas de certo com vantagem e eficácia, iriam melhorando as condições morais de existência desses seres, que vivem no seio da civilização em um estado de barbárie relativa. (CARMO, 1864, p. 3)

O clero do qual fala o presidente é, ainda, o típico do clero regalista brasileiro que se via envolvido em tudo - especialmente na política e no comércio - e muito pouco com as coisas próprias de seu ministério. 
Esses padres, assim, não estavam ajudando na difusão da moral do evangelho e melhoramento das condições morais dos paranaenses, deixando de cumprir esse dever que o Estado Regalista, que os mantinha inclusive financeiramente, deles esperava. Para agravar a questão, os padres existiam em número insuficiente no Paraná, como lembram a todo momento os mesmos relatórios presidenciais, assim como os pedidos de moradores solicitando ao governo da província que conseguisse para determinada localidade a presença de um clérigo para administrar os sacramentos e atender à povoação.

Nesse contexto, duas eram as opções que se abriam para sanar, em parte, a questão: de um lado, a escola primária, na qual o professor deveria fazer sua parte no ensino da doutrina. Do outro, a ação da família. Ambas, voltadas não para o homem adulto e criminoso (que, quando apanhado, era de se esperar, ficasse agrilhoado em uma das precárias cadeias paranaenses), mas para a criança, por meio da qual as chances de construção de uma nova realidade eram bem maiores. Ademais, é sobre a crença na educabilidade da criança que recaíam as esperanças de obter a tão desejada moralização e tempero da população pela educação religiosa. Como as escolas eram pouco frequentadas, sendo seu alcance nessa matéria visivelmente limitado, era com a ação da família que, sem ter outra opção mais palpável, a elite dirigente da província acabava tendo de contar para o alcance de suas aspirações. Mas, mesmo essa instância, na ótica dos administradores, não desempenhava a contento o papel que lhe cabia. Sobre isso, o presidente Carlos Augusto Ferraz de Abreu, em seu relatório acerca do estado da Província em 1869, é bastante esclarecedor:

É uma desoladora verdade, cuja prova se evidencia nos quadros da estatística criminal, que a vida e a propriedade estão muito longe das garantias que a Constituição promete. [...] Como não seria novidade para $V$. Excia a enumeração das causas que originam o fato social a que me reporto, deixo de fazê-la. Entretanto, obedeco a um impulso irresistível manifestando a $\mathrm{V}$. Excia que quanto a mim, a principal delas é a carência de educação. Em tese, a criança não encontra no lar doméstico o ensinamento consentâneo com o seu aperfeiçoamento moral. Na escola, se ela vai, aprende apenas os rudimentos de instrução primária; adquirindo simultaneamente maus hábitos, que, no correr da existência, assumem proporções assustadoras. Depois, sendo recebida na sociedade, onde os bons exemplos desaparecem na causal dos perniciosos, torna-se homem feito, o ludíbrio das paixões e dos vícios. É que faltou-lhe na infância o emprego da profilaxia da educação moral e religiosa para fortalecê-lo contra a ação dos agentes que tinham de atuar sobre si mais tarde. Diga-se francamente a verdade: nem os pais, 
nem os professores ensinam à geração que se forma os salutares preceitos do Evangelho, que constituem as virtudes. E a mocidade, sem a redenção da religião, entregue aos assombros da inexperiência, soletra a descrença no livro do futuro, percorrendo o plano inclinado dos erros, que conduz aos crimes hediondos, à completa perversão moral. (ABREU, 1869, p. 3)

O problema da falta de educação para o presidente começava não na escola, mas em casa, onde "a criança não encontra no lar doméstico o ensinamento consentâneo com o seu aperfeiçoamento moral”. O político preocupava-se com a educação dessas novas gerações porque, a exemplo de seus pares intelectuais, via na criança o homem do amanhã, a ponto de considerar que os maus hábitos, "no correr da existência, assumem proporções assustadoras”. Ao olhar para os infratores no presente, ele convidava os membros da assembleia provincial a refletirem sobre a criança que aqueles criminosos um dia foram; crianças para as quais faltou "na infância o emprego da profilaxia da educação moral e religiosa”. O detergente necessário para ensaboar bem a alma do paranaense e torná-lo limpo e apto a submeter-se à ordem social em implantação naquele território do Império era a educação religiosa dada pela família à criança.

Mas que tipo de educação exatamente os presidentes da província imaginavam que deveria ser dada pelos pais aos filhos? Sem dúvida, era aquela educação religiosa de matriz regalista presente em catecismos como o do Montpellier, que propunha um modelo de relações sociais e familiares desejado por esses agentes burocráticos e pelo próprio Estado Imperial, baseado em uma relação de submissão e obediência à autoridade, a ser aprendido desde a infância, a fim de que a criança, educada nesses moldes, se tornasse o adulto morigerado e cordato, que caminhasse distante da senda do crime e devidamente alinhado às diretrizes que emanavam da lei e das condutas sociais por ela propugnadas. Vejamos como isso era apresentado na interpretação dada pelo Catecismo de Montpellier ao quarto mandamento, que, se posta em prática pelas famílias, possibilitaria - ao menos no plano das representações - uma educação garantidora dos comportamentos almejados para a população, partindo das relações entre pais e filhos para chegar às relações da família com a sociedade e o Estado brasileiro em formação.

\section{O QUARTO MANDAMENTO: UMA PROPOSTA DE EDUCAÇÃO NO CATECISMO DE MONTPELLIER}

O Catecismo de Montpellier, na sua versão pequena, ${ }^{6}$ continha 89 breves lições divididas em três grandes partes. A parte I apresentava 37 lições dedicadas a temas como a História Sagrada, História da Igreja,

Com efeito, O Catecismo de Montpellier possuía três versões: o catecismo mais longo e com mais explanações, para uso dos padres, o catecismo para uso dos meninos da escola e o catecismo para crianças que ainda não sabiam ler. Originalmente, os três catecismos

apareceram reunidos em um único volume. Por questão de comodidade, e para facilitar seu uso nas escolas e entre as famílias, surgiu a versão que tenho chamado de "Catecismo Pequeno", contendo apenas os dois últimos catecismos mencionados. Neste trabalho, utilizarei a edição do "Catecismo Pequeno" impressa na Bahia, em 1817, existente no acervo da Biblioteca Brasiliana José e Guita Mindlin da Universidade de São Paulo. 
Fundamentos da Igreja e Fundamentos da Fé, conforme enunciados no Símbolo dos Apóstolos, o Credo. A parte II continha 28 lições tratando da exposição da ideia geral da vida cristã, da noção do pecado, das virtudes teologais (fé, esperança e caridade), das virtudes morais, dos Dez Mandamentos da Lei de Deus, dos Mandamentos da Igreja e das Bemaventuranças. Por fim, a parte III abordava, ao longo de 24 lições, a polêmica Doutrina da Graça, os sacramentos, a oração, o sacrifício da missa e o Pai Nosso. É na Parte II, Lição XIII, na explicação do quarto mandamento de Deus (“Honrar Pai e Mãe”), que encontramos o fundamento central da educação regalista familiar: a submissão à autoridade paterna e, através dela, às demais, com base em pressupostos de ordem religiosa.

A lição supracitada apresentava, primeiramente, o terceiro mandamento, acerca da necessidade de guardar o dia do Senhor. Em seguida, interrogando o fiel (na pedagogia catequética de perguntas e respostas que visava à memorização da doutrina), começava assim:

\section{P.: $\bigcirc$ que nos ordena o mesmo Senhor no quarto mandamento, expressado nestes termos: Honrarás a teu pai, etc.?}

R.: Prescreve as obrigações dos filhos a respeito de seus pais e mães e, geralmente, dos inferiores a respeito de seus superiores. (CATECISMO DE MONTPELLIER, 1817, p. 117)

Os Mandamentos, como o próprio nome sugere e a pergunta do catecismo reforça, não eram questão de livre aceitação, mas de uma ordem divina, que não cabia ser discutida, mas colocada em prática. A pergunta poderia ser sobre "o que nos diz", "o que nos pede", "o que nos conta” o quarto mandamento. Mas ela é feita com precisão cirúrgica e legalista: “o que nos ordena”. O uso do "etc.” no mandamento completo se justifica porque, na metodologia utilizada, o Decálogo já havia sido apresentado anteriormente, na Lição IX. Mas, na íntegra, a única coisa que essa dizia era: "Honrarás a teu pai, e a tua mãe” (CATECISMO DE MONTPELLIER, 1817, p. 118). Desse modo, é na interpretação dada ao mandamento na Lição XIII que começamos a adentrar na fundamentação regalista que tanto agradou Pombal, no século XVIII, quanto o Estado Brasileiro em formação, no século XIX.

O mandamento "honrar pai e mãe" prescreve - ensina o Catecismo de Montpellier - as obrigações dos filhos a respeito de seus pais e mães e, "geralmente" - isto é, de maneira generalizante e generalizadora - dos inferiores a respeito de seus superiores. Numa sociedade fortemente hierarquizada como a brasileira, tal qual recordam os estudos de Ilmar Mattos (1987), sobre a formação do Estado Imperial, e Jurandir Malerba (1994), acerca do ordenamento jurídico-criminal do Império, as interpretações contidas no catecismo eram bastante favoráveis à sua manutenção. Lembravam aos filhos, por um lado, o dever sagrado de obediência 
a seus pais e, por outro, a seus superiores na hierarquia social. No caso da obediência ao pai e à mãe, é preciso considerar que a ênfase pode ter recaído mais sobre o primeiro, já que a mãe brasileira, embora não tão submissa como por tanto tempo lhe pintaram os historiadores homens (COSTA, 2007), era coagida pelos costumes e pela lei a ser também obediente e dócil ao esposo, posto que, apesar da participação mais ativa na cena social (que vem sendo identificada na historiografia recente), seu papel ainda era "limitado, face à manutenção dos privilégios masculinos” (SAMARA, 1987, p. 58).

No caso da obediência aos superiores, quem, acima do pai, seria o superior do filho? Quem tinha autoridade tanto sobre o pai como sobre o filho? o Imperador, mas que exercia tal poder, sobretudo, por meio dos seus administradores mais próximos, geralmente bacharéis em Direito, metidos na política e na organização da máquina administrativa em gestação, em suas mais variadas instâncias. Como delineou Sérgio Adorno em seu clássico estudo sobre a formação jurídica no Império, “o Estado brasileiro erigiu-se como um Estado de magistrados, dominado por juízes, secundados por parlamentares e funcionários de formação profissional jurídica” (1988, p. 78). Destarte a submissão aos superiores podia, por exemplo, no caso paranaense que vimos na seção anterior, representar a submissão ao chefe de polícia, ao juiz ou ao presidente da Província, ambos, elos de uma cadeia de poder que chegava ao próprio Rei, o defensor perpétuo da Nação e da Constituição, como o definia a própria Carta Magna. Significava também o respeito à propriedade e à segurança individual que o Estado buscava proteger por meio das leis elaboradas por seus políticos-bacharéis e cujas ameaças e desrespeitos eram a causa da lamúria dos administradores provinciais, que viam na educação religiosa a solução para o problema.7

Não podemos esquecer que a sociedade em que esse catecismo dava-se para ler e doutrinar era também uma sociedade escravista na qual a relação entre superior e inferior podia igualmente ser compreendida como a relação do escravo com seu senhor, uma vez que o escravismo atravessava visceralmente todas as relações sociais, do público ao privado, como observou Luiz Felipe de Alencastro:

Havia, portanto, uma ordem privada específica, escravista, que devia ser endossada nas diferentes etapas de institucionalização do Império. Os condicionantes históricos deste processo configuraram duradouramente o cotidiano, a sociabilidade, a vida familiar e a vida pública brasileira. Neste sentido [...] o escravismo não se apresenta como uma herança colonial, como um vínculo com o passado que o presente oitocentista se encarregaria de dissolver. Apresenta-se, isto sim, como um compromisso para o futuro: o Império retoma e reconstrói a escravidão no quadro do direito

7 Particularmente útil, neste ponto, era a interpretação dada pelo catecismo ao crime do furto - que o respeito a Deus e à obediência à autoridade (com seus apanágios) deviam afastar da vida do sujeito bem educado na religião. "P.: Que nos proíbe Deus no sétimo mandamento expressado nestes termos: Não furtarás? R.: Proíbe as injustiças e os danos, que se podem causar ao próximo e aos seus bens [...] P.: A que estamos obrigados, quando temos cometido alguma dessas injustiças ou quando temos sido participantes delas? R.: Estamos obrigados a restituir todo o dano que se causou" (CATECISMO DE MONTPELLIER, 1817, p. 121-122), Em relação aos crimes contra a vida, a doutrina do catecismo também vinha a calhar: "P.: Que nos proíbe Deus pelo 5o Mandamento, expressado nestes termos: Não matarás? R.: Proíbe com essas palavras tudo aquilo que injustamente pode causar dano ao próximo na sua pessoa. [...] P.: Que devemos fazer quando tivermos causado dano ao próximo na sua pessoa? R.: Devemos repará-lo o mais depressa que nos for possível" (CATECISMO DE MONTPELLIER, 1817, p. 119-120) 
Não se pode, logicamente, afirmar categoricamente que tal tenha sido a leitura feita frequentemente dessa relação superior/inferior evocada pelo Catecismo de Montpellier. Mas não se deve desconsiderar que ela era bastante oportuna para reforçar, pela via religiosa, essa peculiaridade da sociedade portuguesa que primeiro traduziu e adotou esse catecismo e que foi herdada, mantida e ressignificada pela sociedade brasileira até quase o último suspiro do Império Regalista.

Que tipo de obrigações seriam essas que os filhos, desde a infância, deveriam aprender a colocar em prática no tocante a seus pais e também aos inferiores a respeito de seus superiores (nos quais, doravante, ficará sugerida também a relação do escravo com seu senhor)? O catecismo definia isso:

\section{P.: Quais são as obrigações dos filhos a respeito de seus pais e dos inferiores a respeito dos superiores?}

R.: As principais são a obediência, o respeito e assistência temporal e espiritual. (CATECISMO DE MONTPELLIER, 1817, p. 117)

Nessa altura, é bom lembrar que nosso catecismo foi produzido originalmente em princípios do século XVIII, quando os resquícios da vassalagem feudal ainda eram encontrados na Europa, apesar do surgimento dos Estados Absolutistas. ${ }^{8}$ Muitos dos camponeses para os quais o catecismo fora originalmente pensado ainda viviam em seu cotidiano a força das relações feudais. Assim, é facilmente compreensível que uma obrigação dos filhos para com os pais - a assistência temporal - fosse estendida também como uma obrigação deles para com os seus superiores. No contexto de fins do Seiscentos e inícios do Setecentos, de fato, muitas vezes os vassalos ainda eram chamados a prestar socorro a seu senhor em guerras ou batalhas e lutas armadas contra inimigos locais. A assistência temporal, portanto, era coisa tão valiosa dentro como fora de casa. Porém, ao transferir isso tudo para o século XIX, é preciso ponderar melhor os novos sentidos que a interpretação poderia ganhar.

Talvez a assistência temporal e a espiritual tenham se tornado mais próprias da família, nas quais aos filhos caberia ajudar os pais, pelo seu trabalho, no sustento da casa e, quando esses já não pudes-

Hobsbawm (2011) observa que, em algumas regiões da Europa - como as habitadas pelos povos eslavos -, essas relações de vassalagem camponesa foram ainda mais longe no tempo alcançando o terceir quartel do século XIX. sem mais trabalhar pela idade, provê-los no alimento, no agasalho e nos demais cuidados. E também garantir que não morressem longe dos sacramentos e da mesma Igreja que, durante toda a vida, regulara suas existências. Porém os dois primeiros comportamentos continuavam plenamente válidos, tanto no tempo como no espaço, tanto aos filhos como aos inferiores: o respeito e a obediência. Respeito às determinações e 
ordens, que podiam partir do pai ou do senhor de escravos mas também do governante e suas leis; obediência, tanto ao pai que tem poder sobre o filho, como ao senhor que tem poder sobre o escravo, como ao Estado, que, com poder para punir e fazer justiça, em nome do Rei, tinha poder sobre a família e cada um de seus membros ou sobre aqueles que dela eram dependentes, como era o caso dos escravos.

Como toda lei que se quer "justa”, esse mandamento não deixa de impor algumas obrigações aos pais e superiores em relação aos filhos e inferiores:

\section{P.: Encerra-se nisso tudo aquilo que prescreve este mandamento? \\ R.: Prescreve também as obrigações dos pais e mães a respeito dos inferiores.}

P.: Quais são as obrigações dos pais e mães a respeito de seus filhos e dos superiores a respeito de seus inferiores?

R.: As principais são o amor, o cuidado, o bom exemplo, socorro e o santo desejo da eterna felicidade. (CATECISMO DE MONTPELLIER, 1817, p. 118)

Nesse ponto do catecismo, todas as aspirações do regalismo são postas a nu. Se até aqui quase tudo que se dizia em relação aos deveres dos filhos era aplicável tanto aos deveres em relação aos pais como aos superiores, na hora de apresentar as obrigações, os superiores claramente saem de cena e elas recaem, exclusivamente, sobre os pais. Com efeito, é sobretudo aos últimos que se pode imputar o “dever" de amar, cuidar, dar bom exemplo, socorro e felicidade. Talvez também se possa cobrar isso do senhor em relação a seu escravo, menos por bondade e mais pela necessidade de dar ao cativo o mínimo necessário para que sua mão de obra pudesse ser utilizada. Mas, no momento em que essa relação de deveres do superior para com o inferior é convertida para o plano da relação governo e governado, fica suficientemente diluída para, praticamente, não ter mais nenhuma importância. Afinal, um governante pode também amar, cuidar, dar bom exemplo e tudo o mais no plano de uma administração política calcada numa relação que até aqui fora mais de deveres do que de direitos, dera amplo espaço para ser interpretada de múltiplas formas, permitindo leituras as mais diversas, sendo justamente essa indefinição o ponto culminante da doutrina religiosa posta a serviço do Estado: dar margem para que as obrigações dos governantes, tal qual exposta no Catecismo, fossem vistas mais como próprias dos pais e dos senhores do que do governante para com os governados. Porém a obrigação desses últimos de respeitar e obedecer era suficientemente clara para que uma relação de poder, chancelada pela doutrina, fosse estabelecida sobre eles, tanto da parte do pai como dos demais superiores. 


\section{CONSIDERAÇÕES E CONCLUSÃO}

Encerrando a análise das representações veiculadas pelo Catecismo de Montpellier relativas ao quarto mandamento, é possível afirmar que a educação que ele difundia - isto é, hábitos, comportamentos e condutas a serem transmitidos pelos pais aos filhos - era um tipo de relação familiar a ser incorporada pelos seus membros, particularmente os filhos, no tempo da infância.

Tendo por base a doutrina católica e o modo como essa entendia o dever filial da obediência paterna, essa relação ensinada e aprendida deveria colaborar para a conformação de uma sociedade de indivíduos igualmente obedientes e dóceis aos superiores na hierarquia social e, indiretamente, às autoridades estatais que materializavam na vida da população a presença e existência do Estado. A obediência paterna, portanto, era desencadeadora de um processo educativo mais amplo que visava a estruturar as relações sociais tanto em âmbito doméstico como coletivo. O quarto mandamento, na interpretação dada pelo Catecismo de Montpellier, oferecia um dos fundamentos estruturadores e estruturantes das próprias relações sociais no Brasil Oitocentista e do papel do Estado e de suas autoridades no ordenamento e orquestramento de tais relações.

Por fim, era desse modo - como propagador da obediência, não só ao pai, mas também às autoridades acima dele, pela interpretação que fazia do quarto mandamento - que o Catecismo de Montpellier servia aos interesses do Estado Regalista.

\section{REFERÊNCIAS}

ADORNO, Sérgio. Os aprendizes do poder. Rio de Janeiro: Paz e Terra, 1988.

ALENCASTRO, Luiz Felipe de. Vida privada e ordem privada no Império. In: ALENCASTRO, Luiz Felipe de. História da vida privada no Brasil 2: Império, a Corte e a modernidade nacional. São Paulo: Companhia das Letras, 1997. p. 11-92.

AZZI, Riolando. A catequese no Brasil: considerações históricas. Convergência, São Paulo, n. 106, p. 491-513, out. 1977.

CHARTIER, Roger. A história cultural: entre práticas e representações. Lisboa: Difel, 2002.

COSTA, Emília Viotti da. Patriarcalismo e patronagem: mitos sobre a mulher no século XIX. In: COSTA, Emília Viotti da. Da monarquia à república. São Paulo: Editora da Unesp, 2007. p. 493-523.

DURAND, Valentin. Le jansénisme au XVIII siécleet Joachim Colbert êvêque de Montpellier (1696-1738). Tolouse: Edouard Privat, 1907.

GRES-GAYER, Jacques. Galicanismo. In: LACOSTE, Jean-Yves. (Org.) Dicionário crítico de teologia. São Paulo: Paulinas; Loyola, 2004. p. 765-769.

HOBSBAWM, Eric. A era do capital. Rio de Janeiro: Paz e Terra, 2011.

MALERBA, Jurandir. Os brancos da lei. Liberalismo, escravidão e mentalidade patriarcal no Império do Brasil. Maringá: Eduem, 1994.

MARTINA, Giácomo. História da Igreja: de Lutero a nossos dias. São Paulo: Loyola, 2003. 
MATTOS, Ilmar Rolhof de. O tempo Saquarema. São Paulo: Hucitec, 1987.

NASCIMENTO, Ester Fraga Villas-Boas. Educar, curar, salvar: uma ilha de civilização no Brasil tropical. Tese (Doutorado em Educação) - Pontifícia Universidade Católica de São Paulo, São Paulo, 2005.

NUNES, Rui Afonso da Costa. História da educação no século XVII. São Paulo: USP, 1981.

OLIVEIRA, Luiz Eduardo; CORREIA, Leda Pires. A importância do catecismo no processo de escolarização. Interdisciplinar, v. 2, n. 2, p. 37-53, jul/dez. 2006.

ORLANDO, Evelyn de Almeida. Por uma civilização cristãa: a coleção Monsenhor Álvaro Negromonte e a pedagogia do catecismo. Dissertação (Mestrado em Educação) - Universidade Federal de Sergipe. Aracaju, 2008.

SAMARA, Eni de Mesquita. A família brasileira. São Paulo: Brasiliense, 1987.

SANTIROCCHI, Ítalo. Os ultramontanos no Brasil e o regalismo do Segundo Império (1840-1889). Tese (Doutorado em História) - Pontifícia Universidade Gregoriana, Roma, 2010.

SANTOS, Cândido dos. O jansenismo em Portugal. Porto: Faculdade de Letras da Universidade do Porto, 2007.

SOUZA, Evergton Sales de. Jansenismo e reforma da Igreja na América portuguesa. In: CONGRESSO INTERNACIONAL ESPAÇO ATLÂNTICO DE ANTIGO REGIME, PODERES E SOCIEDADE, 2 a 5 de novembro de 2005. Lisboa. Anais... Lisboa: IICT, 2005. Mimeografado.

TAMBARA, Elomar. Bosquejo de um ostensor do repertório de textos escolares utilizados no ensino primário e secundário no século XIX no Brasil. Pelotas: Seiva, 2003.

TAMBARA, Elomar. Da leitura do catecismo à catecização da leitura - o catecismo como texto de leitura na escola primária no Brasil do século XIX. In: SIMPÓSIO NACIONAL DE HISTÓRIA, 23., 2005, Londrina. Anais... Londrina: ANPUH, 2005. Disponível em: <http:/|anais.anpuh.org/ wp-content/uploads/mp/pdf/ANPUH.S23.0323.pdf > ou CD ROM.

TEIXEIRA, Giselle Baptista. Compêndios autorizados, saberes prescritos: uma análise da trajetória de livros nas escolas da Corte Imperial: relatório de pesquisa. Rio de Janeiro: Biblioteca Nacional, 2008.

WERNET, Augustin. A Igreja paulista no século XIX: a reforma de D. Antonio Joaquim de Melo. São Paulo: Ática, 1987.

\section{FONTES}

ABREU, Carlos Augusto Ferraz de. Relatório apresentado ao ilustríssimo Senhor Dr. Antonio Augusto da Fonseca pelo $1^{\circ}$ Vice-Presidente Carlos Augusto Ferraz de Abreu por ocasião de entregar-lhe a administração da Província do Paraná. Curitiba: Typographia Paranaense de Cândido Martins Lopes, 1869.

CARMO, José Joaquim do. Relatório com que o Exm. Sr. Dr. José Joaquim do Carmo passou a administração desta Província ao Exm. Sr. Dr. André Augusto de Pádua Fleury no dia 18 de novembro de 1864. Curitiba: Typographia Paranaense de Cândido Martins Lopes, 1864.

CARVALHAES, José Antonio Vaz de. Relatório apresentado à Assembleia Legislativa do Paraná no dia 7 de janeiro de 1857 pelo Vice-Presidente José Antonio Vaz de Carvalhaes. Curitiba: Typographia Paranaense de Cândido Martins Lopes, 1857a.

CARVALHAES, José Antonio Vaz de. José Antonio Vaz de. Relatório apresentado ao Exmo. Senhor Doutor Francisco Liberato de Matos pelo Vice-Presidente José Antonio Vaz de Carvalhaes. Curitiba: Typographia Paranaense de Cândido Martins Lopes, 1857b.

CATECISMO DA DIOCESE DE MONTPELLIER impresso por ordem do Bispo Carlos Joaquim Carlos Colbert traduzidos na língua portuguesa para por eles ensinar a doutrina cristã aos meninos nas escolas dos Reinos e Domínios de Portugal. Bahia: Typographia de Manoel Antonio da Silva Serva, 1817.

MENEZES, Rodrigo Octávio de Oliveira. Relatório com que o Exmo. Sr. Dr. Rodrigo Octávio de Oliveira Menezes passou a administração da província ao primeiro Vice-Presidente Exm. Sr. Conselheiro Jesuíno Marcondes de Oliveira e Sá no dia 31 de março de 1879. Curitiba: Typographia Perseverança, 1879. 
REZENDE, Teóphilo Ribeiro de. Relatório do estado da Província do Paraná apresentado ao Vice-Presidente Henrique de Beaurepaire Rohan. Curitiba: Typographia Paranaense de Cândido Martins Lopes, 1855 .

ROHAN, Henrique de Beaurepaire. Relatório apresentado à Assembleia Legislativa Provincial do Paraná no dia $1^{\circ}$ de março de 1856. Curitiba: Typographia Paranaense de Cândido Martins Lopes, 1856.

JUAREZ JOSÉ TUCHINSKI DOS ANJOS

Professor colaborador do Programa de Pós-Graduação em Educação - PPGE - da Universidade Federal do Paraná - UFPR -, Curitiba, Paraná, Brasil; professor adjunto da Faculdade de Educação da Universidade de Brasília - UnB -, Brasília, Distrito Federal, Brasil

juarezdosanjos@yahoo.com.br 